\title{
Childhood overweight and obesity - analysis of the risk factors, including the patient's family's lifestyle, based on research results collected from two academic centres in Poland
}

\author{
Tomasz Machałowski', Justyna Młyńczyk², Malwina Piskozub², Karolina Niedzielska', \\ Elżbieta Krzywińska-Zdeb3, Maria Piotrowska-Depta ${ }^{4}$ \\ 'Student Scientific Circle of Congenital Metabolic Diseases at the Clinic of Paediatrics, Endocrinology, Diabetology, \\ Metabolic Diseases, and Cardiology of Developmental Age, Pomeranian Medical University, Szczecin, Poland \\ ${ }^{2}$ Students Scientific Circle at the Department of Paediatrics, Rheumatology, Immunology, and Metabolic Bone Diseases, \\ Medical University of Bialystok, Bialystok, Poland \\ ${ }^{3}$ Clinic of Paediatrics, Endocrinology, Diabetology, Metabolic Diseases, and Cardiology of Developmental Age, \\ Pomeranian Medical University, Szczecin, Poland \\ ${ }^{4}$ Clinic of Paediatrics, Rheumatology, Immunology, and Metabolic Bone Diseases, Medical University of Bialystok, \\ Bialystok, Poland
}

\section{ABSTRACT}

Introduction: Approximately 15\% of school-age children in Poland are overweight or obese. This poses a huge problem, considering the health consequences of excessive body weight.

Aim of the study: The aim of this study was an analysis of risk factors for the development of obesity including the family's lifestyle, based on research results collected from two academic centres in Poland (Szczecin and Białystok).

Material and methods: A self-made questionnaire was administered to a group of parents with children aged from two to 17 years. Eighty responses picked at random, 40 from each city, were qualified for further analysis according to the exclusion criteria. Participation in the study was voluntary and anonymous.

Results: In the study group, $24 \%$ of children had an excessive body weight. For the purpose of further analysis, only these children were evaluated. The analysis of nutritional habits showed that $63 \%$ of children ate more than five full meals a day, not including snacking. About $65 \%$ of respondents consumed high-calorie snacks between the main meals. Meals were often irregular and excessive. Half of the respondents did not consume an adequate amount of fluids. Physical activity analysis has shown that $74 \%$ of children were physically active a minimum of 3-4 times a week for at least 30 minutes a day. $47 \%$ of parents reported not to engage in any physical activity. Parents of overweight children, who admitted to not consulting a doctor, amounted to $84 \%$. The main differences between the cities were associated with the daily amount of meals eaten by children. Conclusions: Obesity is not solely a result of unbalanced nutrition. The factors that primarily contribute to obesity involve the family's daily habits.

\section{KEY WORDS:}

obesity, children, epidemiology, overweight, adolescents.

\section{ADDRESS FOR CORRESPONDENCE:}

Tomasz Machałowski, Student Scientific Circle of Congenital Metabolic Diseases at the Clinic of Paediatrics, Endocrinology, Diabetology, Metabolic Diseases, and Cardiology of Developmental Age, Pomeranian Medical University, 1 Unii Lubelskiej St., 71-242 Szczecin, Poland, e-mail: tomasz.machalowski@poczta.onet.pl 


\section{INTRODUCTION}

Over the last 20 years, the population of children in Poland with an excessive body mass has almost doubled. According to the research conducted by the Institute of Mother and Child between 1994 and 1995, the number of overweight and obese school-aged children was 8.7\% [1]. According to the 2014 Health Behaviour in School-aged Children (HBSC) study, excessive body mass among Polish children was noted in $14.8 \%$ of respondents [2]. This is a growing problem among children and adolescents. According to the 2002 International Obesity Task Force (IOTF) report, the percentage of Polish 11-year-olds who exhibited excessive body mass was $20.8 \%$ among boys and $16.5 \%$ among girls. In the 2010 report, that percentage had grown to $25.4 \%$ in boys and $17.9 \%$ in girls. In the group of 13-year-olds a significant increase in overweight and obesity has been noted. The percentage among boys was $16.9 \%$ in 2002 and $21.9 \%$ in 2010 . In girls it was $10.3 \%$ in 2002 and $14.7 \%$ in 2010 [3]. Judging by the rate at which the number of children with excessive body weight is increasing, it is expected that every year this group will grow by approximately 400,000, of which up to 80,000 will be obese [4].

Excessive body weight is a problem on a global scale. According to the 2004 IOTF report, over 150 million children in the world are overweight and $40 \%$ are obese [5]. Studies show a correlation between lifestyle and weight [6]. In the era of so-called health conscious consumerism and fitness, the growing number of obese people is puzzling.

Obesity and overweight are the leading causes of multi-organ and systemic diseases. In endocrinology, it is known that an excessive body mass contributes to the development of type 2 diabetes, hypogonadism, and precocious puberty. Among the cardiovascular pathologies, it is most commonly tied to the development of hypertension and consequent atherosclerosis in adulthood. It also increases the risk for dyslipidaemia (an increase in LDL cholesterol, decrease in HDL cholesterol, increase in triglycerides) and stroke. Excessive body weight can also lead to pulmonary (sleep apnoea, asthma) or orthopaedic complications (postural defects, flat feet). With regard to gastrological disorders, it results in fatty liver and gallstones [7]. Obesity is also proven to contribute to the development of psychological disorders. Obese children are often discriminated against by their peers and have reduced self-esteem. Some may develop symptoms of depression [8] and even anorexia nervosa or bulimia [9].

Weight gain is typically attributed to an imbalance in the number of calories consumed versus those burned [10]. Low physical activity, poor eating habits, diseases, and genetic factors are all common causes of this imbalance [11].

Relevant studies link childhood obesity with the likelihood of obesity in adulthood [12]. Freedman et al. (Bo- galusa Heart Study) stated that $5 \%$ of children $(n=1161)$ with a BMI in the $50^{\text {th }}-95^{\text {th }}$ centile range, while as many as $84 \%$ of those with a BMI in the $95^{\text {th }}-98^{\text {th }}$ centile and $100 \%$ of those with a BMI in and above the $99^{\text {th }}$ centile suffered excessive body weight in adulthood [13].

\section{AIM OF THE STUDY}

To turn the spotlight on the issue of excessive body weight among children, discuss its repercussions, encourage undertaking preventive actions, and display the role of familial background in the development of overweight and obesity.

\section{MATERIAL AND METHODS}

Eighty children (40 from Szczecin and 40 from Bialystok) between the age of 2 and 17 years were randomly selected to participate in the study from a survey conducted between March and April of 2017. None of those selected were prescribed any diets or treatments for longterm conditions (including steroids, anticonvulsants, or antidepressants). Obese patients with a history of allergy and various chronic diseases such as diabetes, phenylketonuria and related metabolic disorders, celiac disease, gastro-oesophageal reflux, hypertension, hypothyroidism, and genetic diseases, were excluded from the study.

Participation in the study was voluntary and anonymous. The study consisted of a questionnaire containing 18 questions, both closed and open-ended. Every question pertained to the child as well as his/her parents. The questionnaire was divided into two parts. The first part concerned diet, place of residence, and type and amount of food consumed. The second part contained questions about physical activity. The survey was administered to the parents of children encountered in educational and health facilities. The questionnaire was filled out on the spot and answered independently by the parents, who also responded for their children. Nonetheless, the authors were present during the process in order to supervise.

\section{RESULTS}

In the examined group of 80 children, $24 \%$ had an excessive body mass (above the $85^{\text {th }}$ percentile), and among them $42 \%$ were obese (above the $95^{\text {th }}$ percentile according to Palczewska's grid). Around 58\% of children with excessive body weight came from Białystok, from among whom $27 \%$ were obese. In the remaining $42 \%$ from Szczecin, $62 \%$ were obese.

Only the overweight and obese children, as well as their parents, were subjected to further analysis.

Boys constituted $68 \%$ of children with excessive body weight and made up the majority of respondent groups in both cities, i.e. $55 \%$ in the Białystok group and $88 \%$ in the Szczecin group. 
Correlation was observed between the child's weight and the weight of his/her family members. As many as $63 \%$ of children with excessive body mass came from families in which at least one parent was overweight or obese. In Białystok and Szczecin the amount of such children was $55 \%$ and $75 \%$, respectively. In $53 \%$ of examinees excess body weight was also observed in other family members (siblings, grandparents).

From the answers obtained, it was established that $79 \%$ of overweight or obese children are children from families in which at least one of the parents had secondary or primary education. In Białystok the number of such children was $73 \%$, and accordingly $88 \%$ in Szczecin.

Familial eating habits were evaluated and number of irregularities in the field of nutrition were found. The most important dietary mistakes included overly abundant and frequent meals. Around $63 \%$ of children with extra body mass consumed more than five abundant meals a day, not counting snacks. Comparison of data collected from both cities showed that the amount of such children was $73 \%$ in the Białystok group and 50\% in Szczecin group. As many as $42 \%$ of children consumed two dinners a day (at home and at school/kindergarten). In Białystok there were $45 \%$ of such children, in Szczecin this percentage was lower and amounted to $38 \%$.

In the group of parents of overweight/obese children, as many as $68 \%$ consumed 3-4 large meals a day. There were about $73 \%$ of such parents in Białystok and $63 \%$ in Szczecin. About $68 \%$ of the parents and $63 \%$ of the children surveyed admitted to snacking between meals. In Białystok, $63 \%$ of parents and $45 \%$ of children snacked between meals about once or twice daily. In Szczecin, the numbers were $75 \%$ and $88 \%$, respectively. Children consumed products such as: fruit (58\%), sweets (47\%), dairy products $(21 \%)$, and salty snacks $(21 \%)$ such as chips. Parents most often consumed fruits (52\%), sweets (42\%), and dairy products (37\%).

Low intake of fluids (from 0.5 to 11 per day) was observed in $47 \%$ of parents and $42 \%$ of children. This trend was noted in $45 \%$ of parents and $45 \%$ of children in Białystok and in $50 \%$ of parents and $38 \%$ of children in Szczecin (Table 1).

All children with excessive body weight expressed a positive attitude towards physical activity, and almost all one of them engaged in it in some form. About $74 \%$ of children performed physical exercises at least 3-4 times a week for a minimum of 30 minutes - mainly running, cycling, and various sports activities at the gym as part of physical education classes. In the comparative assessment of physical activity in both cities, it was shown that the number of children exercising at the abovementioned frequency equalled to $82 \%$ in Białystok and $63 \%$ in Szczecin.

Differences in exercise frequency were noted between the sexes: half of the girls exercised 1-2 times a week, while only $8 \%$ of the boys did so. The majority of boys (84\%) exercised at least 3-4 times a week.
TABLE 1. Familial eating habits

\begin{tabular}{|l|c|c|}
\hline Habit & Parents (\%) & Children (\%) \\
\hline Meals & & \\
\hline $1-2 \times /$ day & 15.8 & 5.25 \\
\hline$>5 \times /$ day & 68.4 & 31.6 \\
\hline Snacks & 15.8 & 63.15 \\
\hline none & 21 & 10.5 \\
\hline $1-2 \times /$ day & 68.5 & 63.25 \\
\hline $3-4 \times /$ day & 5.25 & 21 \\
\hline$>5 \times /$ day & 5.25 & 5.25 \\
\hline Fluids & 47.4 & 42.15 \\
\hline $0.5-1$ l/day & 47.4 & 52.6 \\
\hline $1-2$ l/day & 5.2 & 5.25 \\
\hline$>2$ I/day & & \\
\hline
\end{tabular}

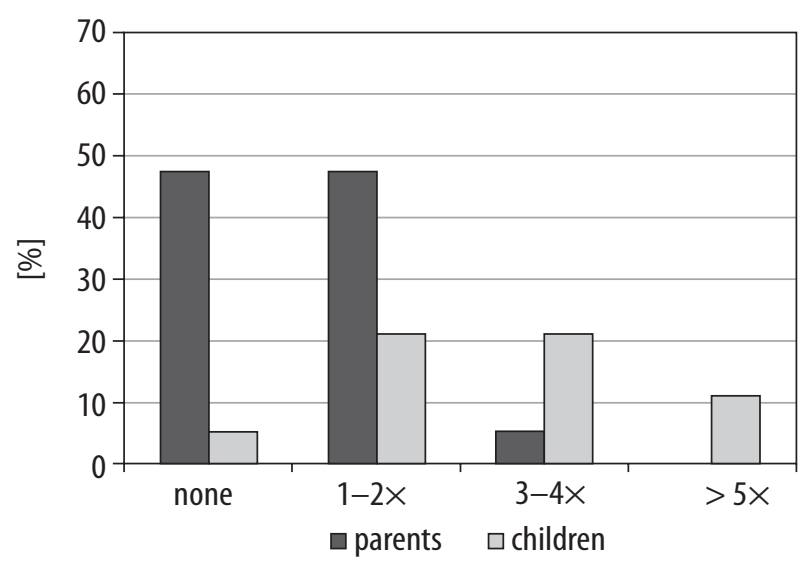

FIGURE 1. Physical exercise per week

Regarding the parents of children with extra body mass, $47 \%$ of them denied any form of physical activity. Another $47 \%$ practiced sports 1-2 times a week, and the remaining 6\% exercised 3-4 times a week. In Białystok, only $9 \%$ of parents were physically active about 3-4 times a week; there were no such parents in Szczecin. Moreover, $79 \%$ of parents did not exercise together with their children (Fig. 1).

For $84 \%$ of parents whose children had excessive body weight, the media (Internet and television) were the primary source of information regarding a healthy lifestyle. At the time of the study they did not consult a doctor or dietician. However, they had formerly sought and subsequently resigned from receiving medical attention. The remaining $16 \%$ stated they continue to consult a doctor. Furthermore, $68 \%$ of all parents of children with extra body mass complained about receiving unhelpful nutritional advice, while $54 \%$ of parents stated that doctors were not willing to spend time and energy in providing 
TABLE 2. Comparison between Szczecin and Białystok

\begin{tabular}{|c|c|c|}
\hline & Szczecin (\%) & Białystok (\%) \\
\hline Meals $>5 \times /$ day - children & 50 & 73 \\
\hline Two diners a day - children & 38 & 45 \\
\hline Snacks $1-2 \times /$ day - children & 88 & 45 \\
\hline Snacks $1-2 \times /$ day - parents & 75 & 63 \\
\hline $\begin{array}{l}\text { Sport activity 3-4×/week - } \\
\text { children }\end{array}$ & 63 & 82 \\
\hline $\begin{array}{l}\text { Sport activity } 3-4 \times / \text { week - } \\
\text { parents }\end{array}$ & 0 & 9 \\
\hline $\begin{array}{l}\text { Medical and dietary } \\
\text { consultations }\end{array}$ & 38 & 0 \\
\hline $\begin{array}{l}\text { Dissatisfaction of medical } \\
\text { advices }\end{array}$ & 100 & 45 \\
\hline Familiar obesity & 75 & 55 \\
\hline
\end{tabular}

such advice. Additionally, $44 \%$ of parents reported that schools and other educational institutions failed to promote healthy eating. Around 38\% of the interviewed parents suggested organising meetings with dieticians during school hours, as well as conducting well-child visits in primary care facilities, and $26 \%$ reported the need for physicians to draw attention to the problems of overweight and obesity during regular visits.

A surprising finding was that up to $100 \%$ of parents in Białystok rejected medical and dietary consultations, whereas in Szczecin the proportion of parents neglecting the consultations was lower and accounted for $62 \%$ (Table 2).

\section{DISCUSSION}

Eating disorders can occur in any period of life and are always dangerous to human health. Obesity negatively impacts body functioning and increases the risk of multiorgan complications.

In the latest Polish cross-sectional studies spanning 10 years (2008-2017), an increase in the body mass of students of all age groups has been observed. In the abovementioned population, $10.5 \%$ of boys and $10.4 \%$ of girls were overweight or obese [14]. Out of all the examined children, $24 \%$ had excessive body weight. Among them, as many as $42 \%$ were obese. In the comparative analysis of both cities, more children with excessive body weight came from Białystok (58\%). In Szczecin, however, there was a higher childhood obesity percentage (62\%).

In many publications, a steadily increasing percentage of children with an excessive body weight has been noted, not only in Poland but globally. Surveys from the National Public Health Institute of the United States showed that almost $17 \%$ of children in the United States between ages two and 19 years were obese. There has been a significant increase over the last three decades. Between the years 1976-1980 and 2007-2008, the percentage of obese children increased from $5 \%$ to $10 \%$ among $2-5$-yearolds. This trend is even more evident in the group of older children, where it increased from $6.5 \%$ to $19.6 \%$ among 6 -11-year-olds, and from $5 \%$ to $18.1 \%$ among 12-19-year-olds [15].

There exists a link between gender and predisposition to develop excess body weight. More often, overweight and obesity concerns boys, who, as mentioned earlier, comprise $68 \%$ of all examined children with excessive body weight. This is in line with the results of the HBSC study of the 2013/2014 school year, which demonstrated that excessive body weight was much more common among Polish boys than girls (19.2\% and $10.4 \%$, respectively) [16]. This tendency is likewise visible both in Szczecin and Białystok ( $88 \%$ and $55 \%$ of children, respectively).

Another important determinant is genetics. Inheritance is polygenic in nature, and mutations can affect genes that regulate metabolism, food intake, and adipocyte maturation. Obesity is more common in identical twins. The body weight of adults raised in foster families is often similar to that of biological parents [17]. Obesity in one parent increases the risk of childhood obesity by $4-5$ times, whereas when obesity affects both parents, the risk is 13 -fold higher. According to our own research, 53\% of children with excessive body weight had at least one individual in their family with the same problem. The results from both cities are consistent in this regard: in Białystok it was $55 \%$ of the examined children and in Szczecin as many as $75 \%$. Similar assertions were confirmed in other studies; according to Indian studies, $32.7 \%$ of obese children had obese parents. Children of obese parents showed more than 25-times greater chance of developing obesity than children from the control group. Moreover, in a family in which the father is obese the son has a 6.5-fold greater chance of developing obesity, whereas the daughter has a 40 -fold greater chance [18].

Socio-economic conditions can favour weight gain, as showcased by the findings of the European Health Interview Survey (EHIS). Many studies indicate that excessive body weight is strongly associated with low socioeconomic status [19]. This is confirmed by research carried out among Czech teenagers aged 10.5-16.5 years in 20022014. In these studies, a correlation was observed between the increase in the percentage of children with excessive body mass and low family income. This was particularly evident in the group of boys [20]. However, there are studies that contradict this observation. A study of primary school students, in the city of Hai Phong in Vietnam, showed that high-income families are more predisposed to gain excessive body mass [21]. This suggests that eating disorders have a cultural, social, and ethnic dimension.

The prevalence of excessive body weight is affected largely by the parents' level of education. Our own findings show that $79 \%$ of children with excess weight came from families in which at least one parent had secondary or primary education. In the comparative analysis between 
Białystok and Szczecin the percentages were $73 \%$ and $88 \%$, respectively. Likewise, studies by other authors pointed to similar conclusions. According to research carried out in Kraków among primary and middle school students, the influence of higher education of parents on the lower number of obese and overweight children was clearly confirmed. In families in which parents finished some form of higher education, the probability of children having excessive body weight was nearly half (18.6\%) that of households in which parents only finished some form of primary or secondary education (40.59\%) [22].

Our own studies traced irregularities in eating habits that also seem to affect weight gain, which can lead to obesity. Snacking and overindulging in food accounted for $90 \%$ of consumption in overweight and obese children, with $63 \%$ of them snacking 1-2 times a day, and $5 \%$ more than five times a day. Snacking also involves selecting easy-to-prepare foods with high caloric content, such as sweets and fast-foods. Snacking often takes place in the evening or at night. Over $63 \%$ of children with extra weight consumed 5-6 meals a day, but also snacked between them (mainly sweets). It was also observed that $42 \%$ of children with excess body mass ate two dinners a day (at home and at an educational facility), exceeding the daily caloric need.

Physical activity is one of the most important aspects that affect the child's mental and physical development. According to the medical literature, regular physical activity reduces the occurrence of overweight by $10-24 \%$ and obesity by $23-43 \%$. On the other hand, watching TV or playing video games causes an increase in the likelihood of developing overweight by $17-44 \%$ and obesity by $10-61 \%$ [23].

To remain physically active should be in the interest of all the family members. Parents should set an example for their children, lead an active lifestyle, and encourage them to exercise. A team of physical activity experts determined the minimum duration of daily physical activity to be 30 minutes, the optimal being one hour. The data from the medical literature shows that only about $30 \%$ of children and adolescents exercise enough to ensure normal physical, psychological, and emotional development [24]. However, only $10 \%$ of adults engage in various forms of activities [25]. Our analysis of results showed that $74 \%$ of children with extra body weight exercised regularly for the recommended minimum of 30 minutes a day, three to four times a week, with more children in Białystok (82\%) than in Szczecin (63\%). Usually this was part of obligatory physical education classes at school or associated with the necessity of walking to/from school. Only $11 \%$ of examined children with excessive body mass stated they exercised for 30 minutes daily. Moreover, almost $80 \%$ of parents did not exercise with their children.

It is crucial to establish cooperation between healthcare professionals and parents regarding the promotion of a healthy lifestyle and the prevention of excessive weight in children. Especially taking into the account the fact that, according to our research, most of the parents of children with extra body weight claimed the nutritional information provided by the doctors or dietitians was insufficient. A portion of parents used other sources of information. For $84 \%$ of parents, the main source of information on healthy eating was the media, mainly the Internet and television. Similar observations were found 15 years ago; over $53 \%$ of patients used the Internet as the first source of information about a proper diet [26].

In general, the role of the familial environment is imperative to the development of excessive body mass in children, as well as its prevention. Research shows that children develop healthy habits by observing their parents [27], especially their mothers, whose behaviour [28], along with education and income, plays a crucial role [29]. The family should lead by example, namely they should prepare the food and engage in physical activity, in order to instil healthy habits in children.

The key challenges of present health care are to improve communication with families, introduce a properly selected diet, encourage daily physical activity, and continue to educate the society about a healthy lifestyle. Listed below are a few recommendations formulated to aid the families of children with an excessive body mass problem:

- The number of calories consumed by the child should not exceed the amount of calories required for his/her normal growth and physical activity.

- The diet should be based on consultation with a doctor or dietician - weight reduction must not disturb the normal growth of a child.

- The best results can be achieved by changing the habits of the whole family (both diet and physical activity).

\section{CONCLUSIONS}

Excessive body weight is a globally increasing problem among children and adolescents, which negatively impacts the child's overall well-being, both physically and psychologically. Familial background is of great importance in the development of extra weight among children, along with lifestyle, which has been shown to be correlated with excessive weight, which is backed by the data collected from Białystok and Szczecin. The prevention tactics for tackling overweight and obesity, as well as cooperation between healthcare professionals and parents, call for improvement. Excessive body weight present in childhood increases the likelihood of obesity in adulthood.

\section{ACKNOWLEDGEMENTS}

We are grateful to the doctors of both clinical centres for their help and support of this research paper. This study was created without the aid of any external financing sources. During the creation of this study, there was 
no indirect or direct conflict of interest. The content presented in the article is consistent with the principles of the Helsinki Declaration, the EU directives, and the unified requirements for biomedical journals.

\section{DISCLOSURE}

The authors declare no conflict of interest.

\section{REFERENCES}

1. Karney A, Oblacińska A, Kluba L, et al. Otyłość dzieci i młodzieży. Współczesne problemy w profilaktyce i terapii. Instytut Matki i Dziecka, Warszawa 2014.

2. Mazur J (ed.). Zdrowie i zachowania zdrowotne młodzieży szkolnej w Polsce na tle wybranych uwarunkowań socjodemograficznych. Wyniki badań HBSC 2014. Instytut Matki i Dziecka, Warszawa 2015.

3. Mazur J. Zdrowie i zachowania zdrowotne młodzieży szkolnej na podstawie badań HBSC 2010. Ośrodek Rozwoju Edukacji, Warszawa 2010: 3-4

4. Karney A, Oblacińska A, Kluba L, et al. Otyłość dzieci i młodzieży. Współczesne problemy w profilaktyce i terapii. Instytut Matki i Dziecka, Warszawa 2014.

5. International Obesity Task Force. Childhood Report. IASO Newsletter, 2004; 6: 10-11.

6. $\mathrm{Ng} \mathrm{M}$, Fleming T, Robinson $\mathrm{M}$, et al. Global, regional, and national prevalence of overweight and obesity in children and adults during 1980-2013. A systematic analysis for the Global Burden of Disease Study 2013. Lancet 2014; 384: 766-781.

7. Sikorska-Wiśniewska G. Nadwaga i otyłość u dzieci i młodzieży. Żywn Nauka Technol Jakość 2007; 6: 71-80.

8. Goodman E, Whitaker RC. A prospective study of the role of depression in the development and persistence of adolescent obesity. Pediatrics 2002; 110: 912-921.

9. Szajewska H. Otyłość u dzieci. Nowa Pediatr 2002; 3: 209-211.

10. Sahoo K, Sahoo B, Choudhury AK, et al. Childhood obesity: causes and consequences. J Family Med Prim Care 2015; 4: 187-192.

11. Plourde G. Preventing and managing pediatric obesity. Can Fam Physician 2006; 52: 322-328.

12. Whitaker RC, Wright JA, Pepe MS, et al. Predicting obesity in young adulthood from childhood and parental obesity. N Engl J Med 1997; 337: 869-873.

13. Freedman DS, Mei Z, Srinivasan SR, et al. Cardiovascular risk factors and excess adiposity among overweight children and adolescents: The Bogalusa Heart Study. J Pediatr 2007; 150: 12-17.

14. Krzyżaniak A (ed.). Zdrowie poznańskich uczniów. Wydawnictwo Miejskie, Poznań 2009.

15. Ogden C, Carroll M. Prevalence of obesity among children and adolescents: United States, trends 1963-1965 through 2007-2008. Retrieved from National Center for Health Statistics, Center for Disease Control and Prevention. http://www.cdc.gov/nchs/data/ hestat/obesity_child_07_08/obesity_child_07_08.pdf (last accessed on 2010).

16. Mazur J. (ed.). Zdrowie i zachowania zdrowotne młodzieży szkolnej w Polsce na tle wybranych uwarunkowań socjodemograficznych. Wyniki badań HBSC 2014. Instytut Matki i Dziecka, Warszawa 2015.

17. Stunkard AJ, Sørensen TI, Hanis C, et al. An adoption study of human obesity. N Engl J Med 1986; 314: 193-198.

18. Kumar S, Raju M, Gowda N. Influence of Parental Obesity on School Children. Indian J Pediatr 2010; 77: 255-258.
19. Pietrzykowska E, Wierusz-Wysocka B. Psychologiczne aspekty nadwagi, otyłości i odchudzania się. Pol Merk Lek 2008; 24: 472.

20. Sigmund E, Badura P, Sigmundova D, et al. Trends and correlates of overweight/obesity in Czech adolescents in relation to family socioeconomic status over a 12-year study period (2002-2014). BMC Public Health 2018; 18: 122.

21. Ngan HTD, Tuyen LD, Phu PV, et al. Childhood overweight and obesity amongst primary school children in Hai Phong City, Vietnam. Asia Pac J Clin Nutr 2018; 27: 399-405.

22. Mleczko E, Szmigiel C. Otyłość i nadwaga dzieci i młodzieży z Krakowa na tle wyników badań rówieśników z innych populacji. Antropomotoryka 2011; 54: 92.

23. Kantomaa MT, Tammelin TH, Demakakos P, et al. Physical activity, emotional and behavioural problems, maternal education and self-reported educational performance of adolescents. Health Educ Res Adv 2009; 10: 1093

24. Tremblay MS, Willms JD. Is the Canadian childhood obesity epidemic related to physical inactivity? Int J Obes 2003; 27: 1100-1105.

25. Wojtczak A. Zdrowie publiczne wyzwaniem dla systemów zdrowia XXI wieku. PZWL, Warszawa 2009: 80-83.

26. Diaz JA, Griffith RA, Ng JJ, et al. Patients' Use of the Internet for Medical Information. J Gen Intern Med 2002; 17: 180-185.

27. Schmitz K, Lytle L, Phillips G, et al. Psychosocial correlates of physical activity and sedentary leisure habits in young adolescents: The Teens Eating for Energy and Nutrition at School Study. Prev Med 2002; 34: 266-278.

28. Sigmund E, Sigmundová D, Badura P, et al. Health-related parental indicators and their association with healthy weight and overweight/obese children's physical activity. BMC Public Health 2018; 18: 676 .

29. Raskind IG, Patil SS, Haardörfer R, Cunningham SA. Unhealthy Weight in Indian Families: The Role of the Family Environment in the Context of the Nutrition Transition. Popul Res Policy Rev 2018; 37: 157-180. 